\title{
ПСИХІЧНИЙ СТАН НАСЕЛЕННЯ ПІД ЧАС ПАНДЕМІЇ COVID-19
}

\author{
Н. О. Рештакова \\ КнП «Обласна клінічна психіатрична лікарня м. Слов'янськ» \\ Тернопільський національний медичний університет \\ імені І. Я. Горбачевського МОЗ Украӥни
}

У статті проаналізовано психічний стан населення, яке опинилося в жорстких умовах карантину під час пандемії COVID-19, а також діагностичні підходи до пацієнтів зі загальної соматичної практики.

\section{MENTAL STATUS OF CITIZENS DURING THE COVID-19 PANDEMIC}

\author{
N. O. Reshtakova \\ Slovyansk Regional Clinical Psychiatric Hospital, \\ I. Horbachevsky Ternopil National Medical University
}

The article analyzes the mental status of the people under severe quarantine conditions during the COVID-19 pandemic, as well as diagnostic approaches to patients on general somatic practice.

Вступ. Наш світ опинився в полоні COVID-19 - кількість інфікованих людей зростає щодня, це лихоліття не оминуло і Україну.

Під час карантинних заходів психічний стан населення значно погіршився. Сьогоднішні реалії стають причиною загальної депресії населення, та, незважаючи на пом'якшення обмежень, чимало людей відчувають стрес та тривогу через необхідність повертатися в офіс, страх їхати в громадському транспорті. Більшість людей стикнулася з дезадаптацією - це порушення здатності пристосування до умов існування, насамперед втрата пристосування до умов соціального середовища. Більш широко - це своєрідний конфлікт між наявною формою життєзабезпечення та зовнішнім середовищем [1].

Основна частина. Соціальні взаємодії часто $є$ головним джерелом серйозних конфліктів та стресу для людини, негативно впливають на фізичне та психічне здоров'я. У багатьох людей реакція на соціальний стрес не $є$ здоровою. Стрес, тривога, депресія стали домінуючими у психічному стані людини. Як результат, головний мозок з його тонкими нейрональними та нейроендокринними системами не встигає адаптуватися до швидких та несприятливих життєвих ситуацій, і ми бачимо дезадаптацію у вигляді збільшення психічних та психосоматичних розладів [2].

(c) Н. О. Рештакова, 2020
На сьогодні дослідження того, як психологічно позначається і позначиться в майбутньому пандемія та карантин на людське життя, тривають. Однак вже частково представлена низка цікавих даних із різних куточків світу про те, як саме людство реагує на COVID-19. Підмічено, що кожна культурна схема (національність) має свої особливості реагування на кризові ситуації, які залежать і від рівня соціальноекономічного розвитку, і від зрілості особистості. Частково це пояснюється різною якістю життя та рівнем освіти [3].

За результатами трьох досліджень, збільшення тривалості карантину погіршувало психологічні наслідки, що призводили до зростання ознак посттравматичного стресового розладу і поведінкових моделей уникнення й гніву.

Результати дослідження продемонстрували глибокий і широкий спектр психологічних наслідків, до яких може призвести спалах COVID-19: поява нових психіатричних симптомів в осіб, які не мають психічних захворювань; погіршення стану тих, хто вже страждає від таких захворювань; дистрес у доглядальників за пацієнтами з психічними та соматичними недугами. До того ж спалах коронавірусної хвороби спричиняє такі суспільні психологічні реакції, як напруження, тривога та страх, втрата орієнтирів і планів на майбутнє, що може також призводити до 
гострої реакції на стрес, посттравматичного стресового розладу, депресії, інших емоційних розладів i, як наслідок, до зростання аутоагресивних дій аж до суїцидальних. Причому психологічний страх (як ірраціональний) стає страшнішим, аніж сама хвороба (об'єктивний страх).

Незалежно від залучення до ситуації, люди за таких умов можуть відчувати безпорадність, острах і занепокоєння з приводу того, що вони захворіють або помруть, або звинувачувати інших, які потенційно можуть спричинити психічний розлад.

Спектр таких психічних порушень може коливатися від депресії, тривоги, панічних нападів, соматичних симптомів та ознак посттравматичного стресового розладу до делірію, психозу та навіть суїциду, які пов'язані з молодшим віком і посиленням самозвинувачення $[4,5]$.

На базі КНП «Обласна клінічна психіатрична лікарня м. Слов'янськ» проведено аналіз звернень за період 9 місяців 2019 р. та 9 місяців 2020 р., дослідження показали, що звернень з діагнозом «Змішаний тривожно-депресивний розлад» у 2020 р. на 15 \% більше, ніж у попередньому (9 \% жінки, 4 \% - первинне звернення в житті). За віковими критеріями виявлено, що $16 \%$ 18-20 років, $28 \%$ - 21-25 років, $35 \%$ - 26-35 років, $11 \%$ - 36-45 років, $10 \%$ - 46 та старше.

3 відібраних історій хвороб за 2020 р. (50 історій) спостерігалась наявність психосоматичних патологій в 26 осіб, що становить $52 \%$, з них у 15 осіб змінився стан внаслідок карантинних заходів.

Даний аналіз дає змогу стверджувати, що в період карантинних заходів населення перебуває не вкрай здоровому психічному стані. Тривога, депресія, панічні розлади збільшуються з кожним днем.

Висновки. Визначено, що вимушена ізоляція та інші карантинні обмеження, викликані пандемією коронавірусу, спричиняють певні трансформації психологічного здоров'я у сфері соціальної взаємодії, особистість вимушена адаптуватися до нових вимог і функціонувати відповідно до них, що потребує певних психологічних ресурсів. Крім того, необхідно зазначити, що ці зміни відбуваються на глибинному особистому рівні та стосуються організації взаємодії людини з іншими, тобто їі соціального контексту, який може набувати ряд негативних характеристик (конфліктність, агресивність, соціальне дистанціювання тощо) і супроводжуватись суб'єктивним відчуттям неблагополуччя.

Для покращення стану не треба нехтувати зверненням до кваліфікованого спеціаліста, на сьогодні дуже багато фахівців надають допомогу он-лайн та щоденно можуть контролювати зміни в стані.

У домашніх умовах під час ізоляції необхідно займатися справами, які підвищують настрій, це час для відкриття нових талантів. Час зробити те, що ви так довго не наважувались через брак часу, та приділити час своїм рідним.

\section{СПИСОК ЛІТЕРАТУРИ}

1. Психологічна підтримка населення: Viber спільнота.

2. Практична психосоматика: діагностичні шкали / О. С. Чабан, О. О. Хаустова, А. Е. Асанова та ін. - К. : Медкнига, 2019. - 112 с.

3. Вплив пандемії COVID-19 та карантину на психологічний стан людини [Електронний ресурс]. - Режим доступу : https://gatne-rada.gov.ua/covid19-doslidzhennyavplivu-15-43-44-23-07-2020/.

4. Чабан О. С. Психічне здоров'я в період пандемії COVID-19 (особливості психологічної кризи, тривоги, страху та тривожних розладів) [Електронний ресурс] / О. С. Чабан, О. О. Хаустова. - Режим доступу : https://neuronews.

com.ua/ua/archive/2020/3\%28114\%29/pages-26-36/ psihichne-zdorov-ya-v-period-pandemiyi-covid-osoblivostipsihologichnoyi-krizi-trivogi-strahu-ta-trivozhnih-rozladiv\#gsc.tab=0.

5. Артюхова В. В. Особливості психологічного здоров'я курсантів в період пандемії COVID-19 [Електронний ресурс] / В. В. Артюхова. - Режим доступу : https:// www.apsijournal.com/index.php/psyjournal/article/ download/991/611. 